\title{
Improved Synthesis of Pyrrolo[1,2-c]pyrimidine and Derivatives
}

\author{
José M. Minguez, Juan J. Vaquero, José L. García-Navio, Julio Alvarez-Builla*
}

Departamento de Química Orgánica, Universidad de Alcalá, 28871-Alcalá de Henares, Madrid, Spain

\begin{abstract}
An improved synthesis of pyrrolo[1,2-c]pyrimidine derivatives by cyclocondensation of pyrrole-2carboxaldehydes with tosylmethyl isocyanide followed by desulfonylation of the resulting 2-tosylpyrrolo[1,2-c]pyrimidines with sodium amalgam is described Copyright @ 1996 Elsevier Science Ltd
\end{abstract}

We became interested in pyrrolo[1,2-c]pyrimidine ${ }^{1}$ as a starting material for a straightforward synthesis of new $\mathrm{N}$-bridged azole systems 3 in which one of the coplanar azole rings is positively charged by quaternization of its bridgehead nitrogen. Such systems exist as a tricyclic cation or alternatively, if internal compensation of the positive charge is accomplished, ${ }^{2}$ as a conjugated mesomeric betaine. We hoped that either the cationic or the heterobetaine structures might exhibit interesting electronic properties associated with charge transfer between the azole-azolium moieties.

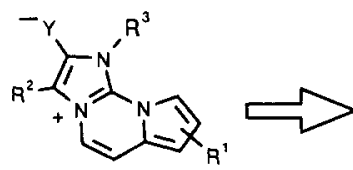

3

$Y=O, S, N R$<smiles>CCn1ccc2nccn21</smiles>

2

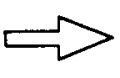

$R^{1}$

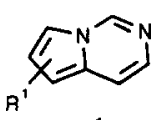

Scheme 1

The retrosynthetic analysis for the target heterobetaine system is shown in Scheme 1. A 1,3-dipolar cycloaddition reaction between a pyrrolo[1,2-c]pyrimidinium salt 2 and heterocumulenes was considered to be the key step in building up the tricyclic system. Hence, our initial synthetic proposal involved a known preparation of the pyrrolo[1,2-c]pyrimidine $1 \mathbf{a}\left(\mathbf{R}^{1}=\mathrm{H}\right)$ as precursor to salt 2a. However, the seven steps synthesis of 1 a described by Rapoport, ${ }^{3}$ which is the only reported procedure (Scheme 2 ) gives an overall yield of less than $1 \%$. This extremely low yield stimulated us to develop an alternative procedure for the synthesis of $1 \mathrm{a}$ and some of its derivatives. In this paper, we report on this improved method along with its scope and limitations. 
The reported synthesis ${ }^{3}$ of the parent pyrrolo[1,2-c]pyrimidine 1a which is outlined in Scheme 2, commences with 4-methylpyrimidine and butyl glyoxalate and contains a final step which furnishes a yield of only $9 \%$. We initially chose a strategy whereby condensation of pyrrole-2-carboxaldehyde $4 a$ with ethyl isocyanoacetate ${ }^{4}$ would lead to the cyclocondensation product 5 a which hopefully could be hydrolised to the corresponding acid $\mathbf{6 a}$, then decarboxylated to give the desired pyrrolo[1,2-c]pyrimidine. Unfortunately $\mathbf{6 a}$ proved to be highly resistant to decarboxylation under various conditions, with 1a being obtained at best in $4 \%$ yield in the best case (refluxing in diphenyl ether for $48 \mathrm{~h}$ ). Attempted decarbonylation of the aldehyde, which was obtained by treating the ester with DIBAL-H (62\%), with Wilkinson's catalyst also failed. Consequently, we decide to attempt the cyclocondensation of the starting aldehyde with tosy lmethyl isocyanide (TOSMIC) $^{4,5}$ in the hope that the resulting sulfone 7 a would be more easily converted into 1 a by reductive displacement of the tosyl group.
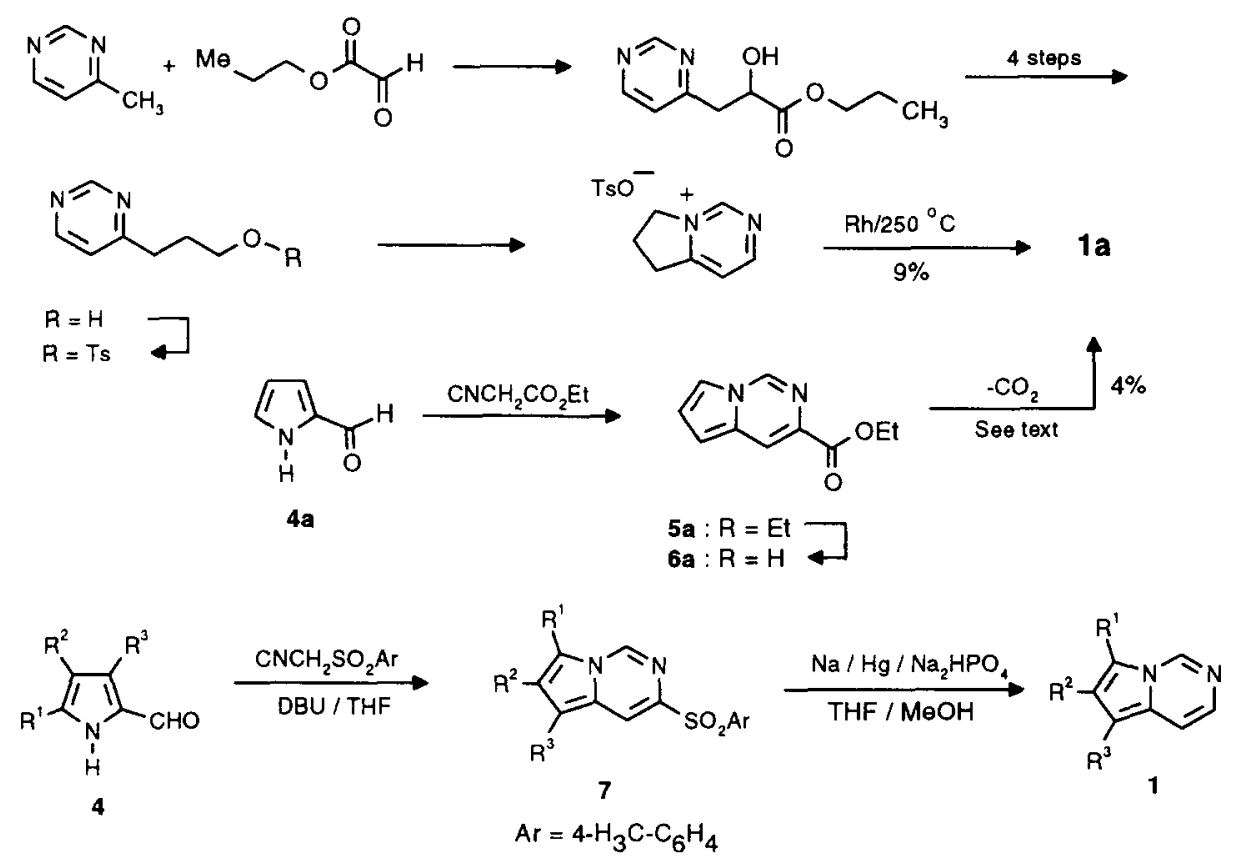

Scheme 2

The reaction of pyrrole-2-carboxaldehyde with TOSMIC gave the cyclocondensation product $7 \mathbf{a}$ in good yield but removal of the tosyl group initially proved troublesome. For example, attempts to desulfonylate $7 \mathbf{a}$ with $\mathrm{H}_{4} \mathrm{LiAl}-\mathrm{NiCl}_{2}{ }^{6}$ afforded $1 \mathrm{a}$ in only $7 \%$ yield, while treatment with $\mathrm{Na}_{2} \mathrm{~S}_{2} \mathrm{O}_{4}{ }^{7}$ gave $1 \mathrm{a}$ in just $18 \%$ yield. Numerous conditions were studied using amalgam, ${ }^{8}$ and the best results were obtained with a $6 \%$ sodium amalgam and $\mathrm{Na}_{2} \mathrm{HPO}_{4}$ in THF-MeOH. ${ }^{8 \mathrm{c}}$ Under these conditions $\mathrm{la}$ was obtained in $51 \%$ yield. 
Table. Pyrrolo[1,2-c]pyrimidine Derivatives 1 Prepared

\begin{tabular}{|c|c|c|c|c|c|c|c|}
\hline \multirow{2}{*}{$\begin{array}{l}\text { Compd } \\
\text { No. }\end{array}$} & \multirow[t]{2}{*}{$\mathbf{R}^{1}$} & \multirow[t]{2}{*}{$\mathbf{R}^{2}$} & \multirow[t]{2}{*}{$R^{3}$} & \multicolumn{2}{|c|}{$7^{\mathrm{a}}$} & \multicolumn{2}{|c|}{$1^{a}$} \\
\hline & & & & Yield (\%) & $\mathrm{mp}\left({ }^{\circ} \mathrm{C}\right)$ & Yield (\%) & $\mathrm{mp}\left({ }^{\circ} \mathrm{C}\right)$ \\
\hline $\mathbf{a}$ & $\mathrm{H}$ & $\mathrm{H}$ & $\mathbf{H}$ & 82 & $200-202$ & 51 & $42-44$ \\
\hline b & $\mathrm{H}$ & $\mathrm{Br}$ & $\mathrm{H}$ & 79 & $223-224$ & $15^{\mathrm{b}}$ & $>300$ \\
\hline c & $\mathbf{H}$ & $\mathrm{Me}$ & $\mathbf{H}$ & 58 & $180-181$ & 77 & $235-237$ \\
\hline d & $\mathrm{H}$ & $n$-Bu & $\mathbf{H}$ & 73 & $100-102$ & 54 & $193-195$ \\
\hline $\mathbf{e}$ & $\mathrm{H}$ & $\mathrm{CH}_{2}=\mathrm{CHCH}_{2}$ & $\mathbf{H}$ & 61 & $237-238$ & 46 & $>300$ \\
\hline $\mathbf{f}$ & $\mathbf{H}$ & $\mathrm{CO}_{2} \mathrm{Me}$ & $\mathbf{H}$ & 69 & $210-212$ & $12^{\mathrm{c}}$ & $98-99$ \\
\hline $\mathbf{g}$ & $\mathrm{Me}$ & $\mathrm{Et}$ & $\mathrm{Me}$ & 69 & $191-192$ & 83 & $272-274$ \\
\hline h & Me & $\mathbf{H}$ & $\mathrm{H}$ & 76 & 203-205 & 74 & $56-57$ \\
\hline i & & $\mathrm{H}$ & H & 80 & 98-99 & 55 & $147-149$ \\
\hline
\end{tabular}

${ }^{a}$ All the compounds exhibited spectral and analytical data consistent with their structure. Compounds $1 \mathbf{b}-\mathbf{e}, \mathbf{1 g}$ and $\mathbf{1 i}$ were isoiated and characterised as hydrobromides. ${ }^{b} \mathrm{~A} 45 \%$ yield of the debromination product (1a) was obtained. ${ }^{c} \mathrm{~A}$ complex mixture was formed.

The procedure was then applied to different substituted pyrrole-2-carboxaldehydes, the results of which are shown in the Table. As expected some functionalities were not compatible with the conditions used in the desulfonylation step. Thus, reductive desulfonylation of $7 \mathbf{b}$ was accompanied by extensive debromination, and $1 \mathrm{~b}$ was obtained in only $15 \%$ yield. Similarly, only a $12 \%$ yield was obtained in the conversion of $7 \mathrm{f}$ into $1 \mathrm{f}$ with a complex mixture being observed.

The preparation outlined for $1 \mathrm{a}$ is representative of the general procedure. 90 a mixture of $214 \mathrm{mg}$ (1.1 mmol) of TOSMIC and $167 \mathrm{mg}(1.1 \mathrm{mmol})$ of DBU in $2 \mathrm{ml}$ of dry THF under argon, $95 \mathrm{mg}$ (1 mmol) of pyrrole-2-carboxaldehyde in $2 \mathrm{ml}$ of anhydrous THF was added. The mixture was stirred at room temperature for $2 \mathrm{~h}$ and then neutralised with acetic acid. The solvent was removed under reduced pressure and the residue was chromatographed on silica gel using Hex-EtOAc (7:3) as eluent. Recrystallization from $\mathrm{CH}_{3} \mathrm{CN}$ gave $223 \mathrm{mg}(82 \%)$ of $7 \mathrm{a}$. To $6 \%$ sodium amalgam ( $184 \mathrm{mg}, 8 \mathrm{mmol} \mathrm{Na}$ ) under argon, a suspension of $639 \mathrm{mg}(4.5 \mathrm{mmol})$ of $\mathrm{Na}_{2} \mathrm{HPO}_{4}$ in $15 \mathrm{ml}$ of anhydrous $\mathrm{MeOH}$ was added. Subsequently, $272 \mathrm{mg}(1 \mathrm{mmol})$ of the sulfone $7 \mathbf{a}$ in anhydrous THF $(10 \mathrm{ml})$ were added. The mixture was stirred at room temperature for 3 $\mathrm{h}$, then it was hydrolyzed with water, and extracted with $\mathrm{Et}_{2} \mathrm{O}(3 \times 10 \mathrm{ml})$. The organic layer was dried over $\mathrm{Na}_{2} \mathrm{SO}_{4}$, the solvent removed under reduced pressure, and the residue chromatographed on silica gel $\left(\mathrm{CH}_{2} \mathrm{Cl}_{2}-\right.$ acetone, $9.5: 0.5)$ to give the pyrrole[1,2-c]pyrimidine $1 \mathrm{a}(60 \mathrm{mg}, 51 \%)$. 
In conclusion, we have developed an efficient method for the synthesis of pyrrolo[ 1,2-c]pyrimidine and some derivatives by the reaction of pyrrole-2-carboxaldehydes with TOSMIC, followed by desulfonylation of the resulting 2-tosylpyrrolo[ $1,2-c]$ pyrimidines. Unlike the previously reported strategy this protocol allows the preparation of this system in synthetically useful yields, though it has some limitations arising from the reductive conditions used for the desulfonylation step. An alternative milder displacement of the tosyl goup is currently being investigated.

Acknowledgement. We thank the Comissió Interdepartamental de Reserca i Innovació Tecnológica (CIRIT) for financial support (project QFN91-4619) and the Ministerio de Educación y Ciencia for a grant (J.M.M.)

\section{References and Notes}

1. For reviews of pyrrolodiazines, see: (a) Amarnath, V.; Madhav, R. Synthesis, 1974, 837-859. (b) Kuhla, D. E.; Lombardino, J. G. Adv. Heterocyclic Chem. 1972, 21, 1-63. (c) Blewit, H. L. Chem. Heterocyclic Comp. 1977, 30, 117-178. (d) Maury, G. Chem. Heterocyclic Comp. 1977, 30, 179-244.

2. Pablo, M. S.; Gandásegui, T.; Vaquero, J. J.; García, J. L.; Alvarez-Builla, J. Tetrahedron, 1992, 48, 8793.

3. Wong, J. L.; Brown, M. S.; Rapoport, H. J. Org. Chem. 1965, 30, 2398

4. Saikachi, H.; Tokujiro, K.; Ssaki, H.; van Leusen, A. M.; Chem. Pharm. Bull. 1982, 30, 4199.

5. (a) van Leusen, A. M.; Siderius, H.; Hoogenboom, B. E.; van Leusen, D. Tetrahedron,1972, 52, 5337.

(b) Barton, D. H. R.; Kervagoret, J.; Zard, S. Z. Tetrahedron, 1990, 46, 7587. (c) Haake, G.; Struve, D.; Montforts, F-P. Tetrahedron Lett., 1994, 35, 9703.

6. Ho, K. M.; Lam, C. H.; Luh, T-Y. J. Org. Chem. 1989, 54, 4474

7. Bremner, J.; Julia, M.; Launay, M.; Stacino, J-P. Tetrahedron Lett. 1982, 23, 3265.

8. Pascali, V.; Umani-Ronchi, A. J. Chem. Soc. Chem. Comm. 1973, 351. (b) Kiddle, J. J.; Green, D. L. C.; Thompson, C. M. Tetrahedron, 1995, 51, 2851. (c) Carr, R. V. C.; Williams, R. V.; Paquette, L. A. J. Org. Chem. 1983, 48, 4976.

9. (7a): IR ( $\mathrm{KBr}) v_{\max } 1594,1348,130 \mathrm{l}, 1147 \mathrm{~cm}^{-1} .{ }^{1} \mathrm{H}$ NMR $\left(300 \mathrm{MHz}, \mathrm{CDCl}_{3}\right) \delta 8.72\left(\mathrm{~s}, 1 \mathrm{H}, \mathrm{H}_{1}\right) 8.25$ $(\mathrm{s}, 1 \mathrm{H}), 7.94(\mathrm{~d}, 2 \mathrm{H}, \mathrm{J}=8.2 \mathrm{~Hz}), 7.49(\mathrm{~d}, 1 \mathrm{H}, \mathrm{J}=2.9 \mathrm{~Hz}), 7.31(\mathrm{~d}, 2 \mathrm{H}, \mathrm{J}=8.2 \mathrm{~Hz}), 7.02(\mathrm{dd}, 1 \mathrm{H}, \mathrm{J}=$ $4.0 \mathrm{~Hz}, \mathrm{~J}=2.9 \mathrm{~Hz}), 6.82(\mathrm{~d}, 1 \mathrm{H}, \mathrm{J}=4.1 \mathrm{~Hz}), 2.41(\mathrm{~s}, 3 \mathrm{H}) \mathrm{ppm}$. MS (m/z, rel intensity) $272\left(\mathrm{M}^{+}, 29\right)$, 207 (18), 139 (18), 106 (100). Anal. calcd. for $\mathrm{C}_{14} \mathrm{H}_{12} \mathrm{~N}_{2} \mathrm{O}_{2} \mathrm{~S}$ : C, 61.75; $\mathrm{H}, 4.44 ; \mathrm{N}, 10.29$; Found: C, 61.50; H, 4.58; N, 10.58. (1a): ${ }^{1} \mathrm{H}$ NMR $\left(300 \mathrm{MHz}, \mathrm{CDCl}_{3}\right) \delta 8.78\left(\mathrm{~s}, 1 \mathrm{H}, \mathrm{H}_{1}\right), 7.36-7.38(\mathrm{~m}, 2 \mathrm{H}), 7.22$ $(\mathrm{d}, 1 \mathrm{H}, \mathrm{J}=6.4 \mathrm{~Hz}), 6.87(\mathrm{dd}, 1 \mathrm{H}, \mathrm{J}=4.0 \mathrm{~Hz} \mathrm{~J}=2.9 \mathrm{~Hz}), 6.43\left(\mathrm{~d}, 1 \mathrm{H}, \mathrm{H}_{5}, \mathrm{~J}=4.0 \mathrm{~Hz}\right) \mathrm{ppm} .{ }^{13} \mathrm{C} \mathrm{NMR}$ $\left(300 \mathrm{MHz}, \mathrm{CDCl}_{3}\right) \delta 138.54,136.09,130.91,115.77,113.12,110.35,99.27 \mathrm{ppm} . \mathrm{MS}(\mathrm{m} / \mathrm{z}$, rel intensity) $118\left(\mathrm{M}^{+}, 100\right), 91(26), 80(28), 63(22)$.

(Received in UK 11 April 1996; accepted 26 April 1996) 